\title{
Successful engraftment after infusion of multiple low doses of CD34+ cells from a poorly matched sibling donor in a patient with severe aplastic anemia
}

\author{
Chang Dae Kum, Mi Jin Lee, Jun Eun Park \\ Department of Pediatrics, Ajou University School of Medicine, Suwon, Korea
}

Received: September 26, 2018

Revised: October 18, 2018

Accepted: October 19, 2018

Corresponding author:

Jun Eun Park

Department of Pediatrics, Ajou

University School of Medicine,

164, Worldcup-ro, Yeongtong-gu,

Suwon 16499, Korea

Tel: +82-31-219-5167

Fax: +82-31-219-5169

E-mail: pedpje@ajou.ac.kr
The dose of CD34+ cells is known to influence the outcome of allogeneic peripheral blood stem cell (PBSC) and/or T-cell-depleted transplantation. A previous study proposed that $2 \times 10^{6} \mathrm{CD} 34+$ cells $/ \mathrm{kg}$ is the ideal minimum dose for allogeneic transplantation, although lower doses did not preclude successful therapy. In the case we present here, CD34+ cells were collected from a matched sibling donor on the day of allogeneic hematopoietic stem cell transplantation; however, the number of cells was not sufficient for transplantation. Consequently, PBSCs were collected three additional times and were infused along with cord blood cells from the donor that were cryopreserved at birth. The cumulative dose of total nuclear cells and CD34+ cells was $15.9 \times 10^{8}$ cells $/ \mathrm{kg}$ and $0.95 \times 10^{6}$ cells $/ \mathrm{kg}$, respectively. White blood cells from this patient were engrafted on day 12. In summary, we report successful engraftment after infusion of multiple low doses of CD34+ cells in a patient with severe aplastic anemia.

Keywords: Aplastic anemia; CD34; Cord blood stem cell transplantation; Peripheral blood stem cell transplantation

\section{Introduction}

Severe aplastic anemia (SAA) is a rare and fatal disease characterized by immune-mediated dysfunction of hematopoietic stem cells [1]. The development of allogeneic peripheral blood stem cell transplantation (PBSCT) has dramatically increased the success rate of SAA treatment [2]. In histocompatible siblings, PBSCT is an effective treatment for SAA $[3,4]$. Allogeneic hematopoietic peripheral stem cell transplantation is beneficial to both donors and recipients: the donor avoids the inconvenience and risk of the collection procedure, including general anesthesia; the patient benefits from a more rapid recovery of the hematopoietic and immune systems, which reduces morbidity and promotes early discharge, compared to bone marrow transplantation [5]. It has been proposed that the minimum number of CD34+ cells in peripheral blood stem cells (PBSCs) required for successful engraftment in allogeneic hematopoietic stem cell transplantation is $2 \times 10^{6}$ cells $/ \mathrm{kg}$. Administration of sufficient numbers of $\mathrm{CD} 34+$ cells to the recipient is an important prognostic factor and is known to affect transplantrelated mortality $[6,7]$. Here, we report a patient with SAA who received PBSCs from their human leukocyte antigen (HLA)-identical sibling. We were, however, unable to harvest a sufficient number of donor PBSCs for engraftment on the day of transplantation. As a result, multiple collections of donor PBSCs were made and infused into the recipient over 4 additional days, together with the donor's cord blood that was cryopreserved at birth. 


\section{Case}

A 6-year-old patient was hospitalized due to pancytopenia identified from the results of a complete blood cell count. At the initial diagnosis, laboratory tests showed a leukocyte count of $3.0 \times 10^{9} / \mathrm{L}$, hemoglobin of $8.5 \mathrm{~g} / \mathrm{dL}$, platelet count of $19 \times 10^{9} / \mathrm{L}$, absolute neutrophil (ANC) count of $0.84 \times 10^{9} / \mathrm{L}$, and corrected reticulocytes at $1.43 \%$. Furthermore, a bone marrow examination revealed hypocellularity (less than $10 \%$ marrow cellularity). After evaluation, the patient was diagnosed with moderate aplastic anemia. In accordance with the criteria of aplastic anemia, immunosuppressive therapy (IST) was performed with antithymocyte globulin (ATG), cyclosporine, and prednisolone (PD). The patient was treated with $3.5 \mathrm{mg} / \mathrm{kg}$ ATG for 5 days, 7.5 $\mathrm{mg}$ PD TID $(1 \mathrm{mg} / \mathrm{kg})$ for 5 days, and $180 \mathrm{mg}$ cyclosporine-A (CSA). No IST response was observed after 6 months, and follow-up testing at this time showed a leukocyte count of $1.8 \times 10^{9} / \mathrm{L}$, hemoglobin of $7.1 \mathrm{~g} / \mathrm{dL}$, platelet count of $13 \times 10^{9} /$ $\mathrm{L}, \mathrm{ANC}$ count of $0.52 \times 10^{9} / \mathrm{L}$, and corrected reticulocytes at $0.40 \%$. The patient was diagnosed with SAA, and an allogeneic hematopoietic stem cell transplant was performed 1 month later. Tests for parvovirus and cytomegalovirus (CMV) were both negative, and the patient also tested negative for congenital bone marrow failure syndromes, including Wiskott-Aldrich syndrome and Fanconi anemia.

The selected donor was the patient's 3 year-old brother, who was HLA- and ABO-matched and blood type $\mathrm{Rh}+\mathrm{O}$. He also tested negative for parvovirus and CMV, and there were no unusual findings in the pre-transplantation evaluation. A $10 \mu \mathrm{g} /$ $\mathrm{kg}$ dose of granulocyte colony stimulating factor (G-CSF) was administered subcutaneously to the donor from day -3 to day 0 , which increased the donor's white blood cell (WBC) count to $20.9 \times 10^{9} / \mathrm{L}$ at day 0 (reticulocyte $2.38 \%$, ANC $1.525 \times 10^{9} / \mathrm{L}$ ).

The condition regimen included intravenous (IV) fludarabine $\left(30 \mathrm{mg} / \mathrm{m}^{2} /\right.$ day from day -6 to day -2$)$, cytoxan $(25 \mathrm{mg} / \mathrm{kg} /$ day from day -6 to day -3$)$, and thymoglobulin $(2.5 \mathrm{mg} / \mathrm{kg} /$ day from day -3 to day -1 ). To prevent graft-versus-host disease (GVHD), a $5 \mathrm{mg} / \mathrm{kg} /$ day dose of IV CSA was administered beginning the day before transplantation (day -2). Additionally, mycophenolate mofetil was administered orally at a dose of $15-20 \mathrm{mg} / \mathrm{kg}$ the day after transplantation.

Hematopoietic stem cells were harvested from the donor after 4 days of G-CSF administration up to the day of transplantation, according to the allogeneic PBSCT protocol. A total volume of $180 \mathrm{~mL}$ (total nuclear cell [TNC] $4.89 \times 10^{8}$ cells $/ \mathrm{kg}, \mathrm{CD} 34+$ $0.36 \times 10^{6}$ cells $/ \mathrm{kg}$ ) was harvested, and mobilized infusion was performed during the first treatment. Since the number of CD34+ cells was much lower than the threshold value, we decided to repeat the PBSCT collection. However, despite performing a total of four PBSC harvests from the donor, the required number of CD34+ cells was not obtained (2nd PBSCT: TNC $3.56 \times 10^{8}$ cells $/ \mathrm{kg}$, CD34+ $0.29 \times 10^{6}$ cells $/ \mathrm{kg}$; $3 \mathrm{rd} \mathrm{PBSCT:}$ TNC $4.90 \times 10^{8}$ cells $/ \mathrm{kg}, \mathrm{CD} 34+0.21 \times 10^{6}$ cells $/ \mathrm{kg}$; 4th PBSCT: TNC $2.39 \times 10^{8}$ cells $/ \mathrm{kg}, \mathrm{CD} 34+0.06 \times 10^{6}$ cells $/ \mathrm{kg}$ ). As a result, we also administered the donor's cord blood cells that were frozen and stored, followed by cord blood infusion with $0.14 \times 10^{8}$ cells $/ \mathrm{kg}$ TNC and $0.03 \times 10^{6}$ cells $/ \mathrm{kg}$ CD34+ cells. The total cell count for the five injections was $15.88 \times 10^{8}$ cells $/ \mathrm{kg}$ TNC and $0.95 \times 10^{6}$ cells $/ \mathrm{kg} \mathrm{CD} 34+$ (Table 1 ).

For engraftment, IV administration of G-CSF $250 \mu \mathrm{g}$ $\left(300 \mu \mathrm{g} / \mathrm{m}^{2}\right)$ was started on day 4 . Twelve days after the first transplantation, WBC engraftment was achieved with a mean neutrophil count $>0.5 \times 10^{9} / \mathrm{L}$. Platelet engraftment without transfusion for over 2 weeks (platelet count $>20 \times 10^{9} / \mathrm{L}$ ) was achieved on day 21 . The donor chimerism result was completely changed when measured 1 month after the first stem cell infusion. After transplantation, the patient showed no signs of acute/chronic GVHD and was discharged from the hospital. The patient maintained complete remission; bone marrow examination results revealed cellularity above $50 \%$, and the donor chimerism value was maintained for a full year.

Table 1. Five transplantation in 5 days, including cord blood from the donor.

\begin{tabular}{lcccc}
\hline Infusion & $\begin{array}{c}\text { Date of } \\
\text { infusion } \\
(\text { day })\end{array}$ & $\begin{array}{c}\text { TNC } \\
\left(\times 10^{8} / \mathrm{kg}\right)\end{array}$ & $\begin{array}{c}\text { CD34+ cell } \\
\left(\times 10^{6} / \mathrm{kg}\right)\end{array}$ & $\begin{array}{c}\text { Stem cell } \\
\text { source }\end{array}$ \\
\hline 1st & 0 & 4.89 & 0.36 & $\mathrm{~PB}$ \\
2nd & 1 & 3.56 & 0.29 & $\mathrm{~PB}$ \\
3rd & 2 & 4.90 & 0.21 & $\mathrm{~PB}$ \\
4th & 4 & 2.39 & 0.06 & $\mathrm{~PB}$ \\
5th & 5 & 0.14 & 0.03 & $\mathrm{CB}$ \\
Total cell count & & 15.88 & 0.95 & \\
\hline
\end{tabular}

TNC, total nuclear cell; $\mathrm{PB}$, peripheral blood; $\mathrm{CB}$, cord blood.

\section{Discussion}

SAA is a heterogeneous disorder of bone marrow stem cells and/or their microenvironment, and can be due to various mechanisms, including autoimmune processes and viral infection [4]. If treated inappropriately, SAA can be a potentially fatal disorder in children. The main approaches to SAA therapy are hematopoietic stem cell transplantation and IST, and for children the current algorithm recommends transplantation, if there is a matched sibling donor. In the absence of a matching donor, IST 
using a combination of ATG and cyclosporine is the first choice of treatment [8-10].

The importance of CD34+ cell dose in PBSCT has been clearly demonstrated in autologous or homogeneous peripheral blood hematopoietic stem cell transplantation. CD34 is a type I transmembrane protein expressed by hematopoietic stem cells, and CD34+ cells have the ability to differentiate into all bone marrow cell lineages. Clinically, CD34+ cells are considered equivalent to pluripotent stem cells, with self-renewing capabilities. The dose of injected CD34+ cells is known to be an important factor in autoimmune and allogeneic stem cell transplantation success [11]. The infusion of large numbers of CD34+ cells in PBSCT is thought to accelerate hematopoietic engraftment and reduce graft-related morbidity $[12,13]$.

In a previous study, Singhal et al. recommended a CD34+ cell dose of $2 \times 10^{6}$ cells $/ \mathrm{kg}$ as the minimum threshold for allogeneic sibling blood or marrow stem cell transplantation [7]. Bittencourt et al. recommended a CD34+ cell dose of $3 \times 10^{6}$ cells $/ \mathrm{kg}$ as optimal for allogeneic BM transplantation in terms of faster engraftment and decreased treatment-related mortality [6]. In 2010, Islam et al. showed that infusion of less than $2 \times 10^{6}$ $\mathrm{CD} 34+$ cells $/ \mathrm{kg}$ was associated with an increased incidence of graft failures, a higher incidence of bacterial infection, and a delay in neutrophil engraftment [11].

In the present case, we injected $0.36 \times 10^{6}$ cells $/ \mathrm{kg}$ CD34+ cells, which is much lower than the previously proposed minimal threshold of $2 \times 10^{6} \mathrm{CD} 34+$ cells $/ \mathrm{kg}$. We administered four PBSC injections with $0.92 \times 10^{6}$ cells $/ \mathrm{kg}$ CD34+ cells, followed by cord blood infusion with $0.14 \times 10^{8}$ cells $/ \mathrm{kg}$ TNC and $0.03 \times 10^{6}$ cells/ $\mathrm{kg} \mathrm{CD} 34+$ cells. Despite the fact that these values were lower than the recommended threshold value, ANC engraftment was successful after 12 days without any additional abnormalities, such as GVHD infection. The result of bone marrow and polymerase chain reaction with short tandem repeat markers showed that the patient maintained full donor chimerism at their 1 month and 1 year follow-up examinations. After the first transplantation, it took 12 days to engraft the ANC, 8 days after the fourth PBSC infusion, and 7 days after the cord blood transplant. Additionally, de la Rubia et al. showed that the median time taken to achieve engraftment with neutrophil counts $>0.5 \times 10^{9} / \mathrm{L}$ was 12 days (range, $9-13$ days) [14]. From this, the first peripherally infused stem cells $\left(\mathrm{CD} 34+0.36 \times 10^{6}\right.$ cells $\left./ \mathrm{kg}\right)$ were considered to have a major influence on engraftment in the present case.

In addition, the donor cord blood cell infusion, which was performed last, is known to contain mesenchymal stem cells (MSCs), which improve the recovery of hematopoietic function and prevents GVHD following hematopoietic stem cell transplantation (HSCT). MSCs are a type of adult stem cell found in many tissues and organs. They are capable of self-renewal, multiple screening, and regulation of immune function. MSCs are progenitors of bone marrow stroma, and MSCs isolated from bone marrow, blood, and cord blood have been shown to promote engraftment after hematopoietic stem cell transplantation. Moreover, MSCs facilitate engraftment of neutrophils and platelets, and contribute to $100 \%$ donor chimerism. MSCs in HSCT can promote stem cell transplantation, improve hematopoietic function recovery, and prevent GVHD [15]. In the present case, it is possible that MSCs facilitated the engraftment of neutrophils and platelets contained in the administered peripheral blood and cord blood stem cells. Additionally, cord blood stem cell infusion may have supplemented the otherwise small CD34+ cell dose. The reason for the insufficient number of CD34+ cells harvested from the donor is not clear. The donor's body weight was $16.9 \mathrm{~kg}$, which is less than the patient, and could be one of the causes of the insufficient harvest. We attempted to further evaluate the donor, but his mother refused.

In conclusion, we report successful engraftment after infusion of multiple low doses of CD34+ cells from a poorly matched sibling donor in a patient with SAA.

\section{Conflicts of interest}

No potential conflicts of interest relevant to this article was reported

\section{ORCID}

Chang Dae Kum, https://orcid.org/0000-0002-0383-8672

Mi Jin Lee, https://orcid.org/0000-0001-6566-3719

Jun Eun Park, https://orcid.org/0000-0003-4292-3500

\section{References}

1. Peinemann F, Grouven U, Kröger N, Pittler M, Zschorlich B, Lange S. Unrelated donor stem cell transplantation in acquired severe aplastic anemia: a systematic review. Haematologica 2009;94:1732-42.

2. Copelan EA. Hematopoietic stem-cell transplantation. N Engl J Med 2006;354:1813-26.

3. Bacigalupo A. Guidelines for the treatment of severe aplastic anemia. Working Party on Severe Aplastic Anemia (WPSAA) of the European Group of Bone Marrow Transplantation 
(EBMT). Haematologica 1994;79:438-44.

4. Young NS, Barrett AJ. The treatment of severe acquired aplastic anemia. Blood 1995;85:3367-77.

5. Charbonnier A, Sainty D, Faucher C, Arnoulet C, Chabannon C, Blaise D. Immune reconstitution after blood cell transplantation. Hematol Cell Ther 1997;39:261-4.

6. Bittencourt H, Rocha V, Chevret S, Socié G, Espérou $\mathrm{H}$, Devergie A, et al. Association of CD34 cell dose with hematopoietic recovery, infections, and other outcomes after HLA-identical sibling bone marrow transplantation. Blood 2002;99:2726-33.

7. Singhal S, Powles R, Treleaven J, Kulkarni S, Sirohi B, Horton C, et al. A low CD34+ cell dose results in higher mortality and poorer survival after blood or marrow stem cell transplantation from HLA-identical siblings: should 2 x 10(6) CD34+ cells/ $\mathrm{kg}$ be considered the minimum threshold? Bone Marrow Transplant 2000;26:489-96.

8. Bacigalupo A. How I treat acquired aplastic anemia. Blood 2017;129:1428-36.

9. Barone A, Lucarelli A, Onofrillo D, Verzegnassi F, Bonanomi S, Cesaro S, et al. Diagnosis and management of acquired aplastic anemia in childhood. Guidelines from the Marrow Failure Study Group of the Pediatric Haemato-Oncology Italian Association (AIEOP). Blood Cells Mol Dis 2015;55:40-7.

10. Killick SB, Bown N, Cavenagh J, Dokal I, Foukaneli T, Hill A, et al. Guidelines for the diagnosis and management of adult aplastic anaemia. Br J Haematol 2016;172:187-207.

11. Islam MS, Anoop P, Datta-Nemdharry P, Sage D, GordonSmith EC, Turner D, et al. Implications of CD34+ cell dose on clinical and haematological outcome of allo-SCT for acquired aplastic anaemia. Bone Marrow Transplant 2010;45:886-94.

12. Pérez-Simón JA, Caballero MD, Corral M, Nieto MJ, Orfao A, Vazquez L, et al. Minimal number of circulating CD34+ cells to ensure successful leukapheresis and engraftment in autologous peripheral blood progenitor cell transplantation. Transfusion 1998;38:385-91.

13. Perez-Simon JA, Diez-Campelo M, Martino R, Sureda A, Caballero D, Canizo C, et al. Impact of CD34+ cell dose on the outcome of patients undergoing reducedintensity-conditioning allogeneic peripheral blood stem cell transplantation. Blood 2003;102:1108-13.

14. de la Rubia J, Cantero S, Sanz GF, Remigia MJ, Monteagudo E, Moscardó F, et al. Transplantation of CD34+ selected peripheral blood to HLA-identical sibling patients with aplastic anaemia: results from a single institution. Bone Marrow Transplant 2005;36:325-9.

15. Le Blanc K, Samuelsson H, Gustafsson B, Remberger M, Sundberg B, Arvidson J, et al. Transplantation of mesenchymal stem cells to enhance engraftment of hematopoietic stem cells. Leukemia 2007;21:1733-8. 